\title{
Genetic Variability, Heritability and Genetic Advance for Yield in Mung Bean [Vigna radiata (L.)Wilczek]
}

\author{
K. Manivelan ${ }^{1 *}$, M. Karthikeyan ${ }^{1}$, K. K. Suvain ${ }^{2}$ and S. Palaniyappan ${ }^{3}$ \\ ${ }^{1}$ Department of Genetics and Plant Breeding, Annamalai University, India \\ ${ }^{2}$ Department of Agronomy, Annamalai University, India \\ ${ }^{3}$ Department of genetics and plant breeding, AC \& RI (TNAU), Madurai, India \\ *Corresponding author
}

\begin{abstract}
Keywords A B S T R A C T

phenotypic coefficient variability, genotypic coefficient of variability, genetic advance, heritability.

Article Info

Accepted:

22 August 2019 Available Online: 10 September 2019

Ten greengram genotypes and their $21 \mathrm{~F}_{1} \mathrm{~s}$ possible cross combinations were evaluated for seven yield and yield attributing traits including yield considerable variability existed for all the traits, the phenotypic and genotypic coefficient of variability (GCV), heritability and genetic advance (GA) were high for seven characters recorded values for heritability among them plant height showed highest heritability followed by Seed yield per plant, Number of pods per plant, Number of branches per plant, Number of clusters per plant, Hundred seed weight (g). High heritability coupled with high genetic advance (GA) as percentage of mean was observed for plant height.
\end{abstract}

\section{Introduction}

Green gram (Vigna radiata (L.)Wilczek) is one of the important pulse crops because of its short growth duration, adaptation to low water requirement and soil fertility. It isfavored for consumption due to its easy digestibility and low production of flatulence (Shil and Bandopadhya, 2007). Pulses are extensively grown in tropical regions of the world as a major protein rich crop bringing considerable improvement in human diet. Average protein content in the seed is around 24 per cent. The protein is comparatively rich in the amino acid lysine but predominantly deficient in cereal grains (Baskaran et al., 2009). Presently, the yield of green gram is well below the optimum level compare to other pulses. The average yield of mungbean is very low not only in India $(425 \mathrm{~kg} / \mathrm{ha})$ but in entire tropical and sub-tropical Asia. Genetic variability studies are an important parameter for identifying key traits that would form a reliable link during selection. Variability studies reveal the extent of genotypic factors controlling the expression of any given trait. Hence, a study was 
conducted to identify the traits with desirable genetic variability for future breeding programmes.

\section{Materials and Methods}

The experimental material consisted of 21 germplasm accessions of green gram (Vigna radiata (L.) Wilczek) obtained from various and maintained at Department of Plant Breeding and Genetics, Annamalai University, Chidambaram. Parent were evaluated in randomized block design with three replication during kharif season. Each genotype was grown in 4-row plots, $6 \mathrm{~m}$ long with $30 \times 10 \mathrm{~cm}$ spacing. The experimental material comprised of ten genotypes of green gram viz., VGG-8, CDM Local, RM8-662, HUM-12, RM8-663, V-3518, Nagalur Local, ADT-2, ADT-3,KM-2. The recommended packages of practices were followed to raise the crop. Data on the basis of five randomly selected competitive plants were recorded on Plant height, Number of branches per plant, Number of clusters per plant, number of seeds per pods, number of pods per plant, hundred grain weight, seed yield per plant.

\section{Results and Discussion}

The results obtained under the present investigation are presented in Table 1 and 2. The pooled analysis of variance of four locations revealed significant differences for all seven characters as presented in Table 1. The mean sum of squares due to treatments was found highly significant for all the twelve characters. A wide range of variability was exhibited by most of the traits under the study. The wide range of variation noticed in all the characters would offer scope of selection for desirable types. All the twelve characters under the study exhibited low GCV and PCV difference indicating the inheritance of plant genetic system with minimum influence of the environment. All the seven characters under the study exhibited low GCV and PCV difference hence, reliable. The highest genotypic coefficient of variation (GCV) and phenotypic coefficient of variation (PCV) were observed for plant height, number of clusters per plant, number of branches per plant, number of pods per plant, hundred seed weight $(\mathrm{g})$, seed yield per plant $(\mathrm{g})$ while it was moderate for number of seeds per pod(Rohit Yadav et al., 2017). Narrow difference between PCV and GCV values of all these traits indicated the predominance of additive gene effects whereas high PCV and GCV traits are highly preferred for selection. In this study, seed yield per plant (g) (99.2839), number of pods per plant(98.1419), number of seeds per pod(95.3781), number of branches per plant(92.6269), number of clusters per plant (91.4814) and hundred seed weight (88.2684) recorded higher values for heritability hence, highly desirable for selection (Mamata et al., 2018).

The higher values of heritability coupled with high genetic advance as percentage of mean was recorded for the character, seed yield per plant (81.2310) which indicated the role of additive gene action and further reveals that the improvement of such traits is easy through selection. Johnson et al., (1955) have suggested that characters with high heritability coupled with high genetic advance would respond better during selection than those with high heritability and low genetic advance. The character like number of branches per plant $(91.4814,6.4429)$, number of seed per plant $(95.3781, \quad 6.0477)$ and hundred grain weight $(88.2684,2.5396)$ recorded, high heritability, with low genetic advance as percentage of mean, revealing the role of nonadditive gene action (Paikhomba et al., 2014). 
Table.1 pooled analysis of variance for yield and yield components in grengram

\begin{tabular}{|l|l|l|l|l|l|l|l|l|}
\hline Source of variance & df & PH & NCP & NBP & NPP & NSP & HSW & SYP \\
\hline Replication & $\mathbf{2}$ & $\mathbf{5 . 6 5 8 6}$ & $\mathbf{2 . 8 0 6 8}$ & $\mathbf{0 . 0 0 1 0}$ & $\mathbf{3 . 1 1 7 5}$ & $\mathbf{0 . 7 9 8 8}$ & $\mathbf{0 . 1 3 9 5}$ & $\mathbf{1 . 0 1 2 1}$ \\
\hline Treatment & $\mathbf{9}$ & $\mathbf{4 0 4 0 . 9 5 7 8}$ & $\mathbf{2 9 7 . 6 6 6 6}$ & $\mathbf{4 2 . 4 7 8 1}$ & $\mathbf{4 0 2 3 . 9 7 7 1}$ & $\mathbf{2 4 7 . 9 2 6 4}$ & $\mathbf{4 8 . 5 4 8 3}$ & $\mathbf{2 5 6 7 . 4 1 1 9}$ \\
\hline Error & $\mathbf{1 8}$ & $\mathbf{1 4 . 0 3 4 0}$ & $\mathbf{1 7 . 9 2 2 6}$ & $\mathbf{2 . 1 9 5 9}$ & $\mathbf{5 0 . 4 7 2 3}$ & $\mathbf{7 . 8 8 2 1}$ & $\mathbf{4 . 1 1 9 1}$ & $\mathbf{1 2 . 3 1 6 3}$ \\
\hline
\end{tabular}

PH - Plant height $(\mathrm{cm}), \mathrm{NCP}$ - Number of Clusters per plant, NBP - Number of branches per plant, NPP - Number of pod per plant, NSP - Number of Seeds per pod, HSW - hundred seed weight (g), SYP - Seed yield per plant (g)

Table.2 Estimations of variability parameters for different characters in green gram

\begin{tabular}{|c|c|c|c|c|c|c|c|}
\hline \multirow[t]{2}{*}{ Trait/Parameters } & \multicolumn{2}{|l|}{ Variance } & \multicolumn{2}{|c|}{$\begin{array}{l}\text { Coefficient } \\
\text { Variance \% }\end{array}$} & \multirow[t]{2}{*}{ Heritability } & \multirow[t]{2}{*}{$\begin{array}{l}\text { Genetic } \\
\text { Advance }\end{array}$} & \multirow{2}{*}{$\begin{array}{l}\text { Genetic } \\
\text { Advance } \\
(\% \text { of } \\
\text { mean })\end{array}$} \\
\hline & PV & $\mathrm{CV}$ & PCV & GCV & & & \\
\hline Plant height (cm) & 150.1849 & 149.4052 & 23.4810 & 23.4200 & 99.4809 & 25.1142 & 48.1198 \\
\hline Number of clusters per plant & 11.6885 & 10.6928 & 26.8876 & 25.7168 & 91.4814 & 6.4429 & 50.6700 \\
\hline $\begin{array}{l}\text { Number of branches per } \\
\text { plant }\end{array}$ & 1.6546 & 1.5326 & 22.7263 & 21.8725 & 92.6269 & 2.4544 & 43.3644 \\
\hline Number of pods per plant & 150.9055 & 148.1015 & 36.1446 & 35.8073 & 98.1419 & 24.8356 & 73.0745 \\
\hline Number of seeds per pod & 9.4744 & 9.0365 & 18.4972 & 18.0646 & 95.3781 & 6.0477 & 36.3430 \\
\hline Hundred seed weight (g) & 1.9506 & 1.7218 & 26.6792 & 25.0654 & 88.2684 & 2.5396 & 48.5115 \\
\hline Seed yield per plant (g) & 95.5455 & 94.8613 & 39.7169 & 39.5745 & 99.2839 & 19.9918 & 81.2310 \\
\hline
\end{tabular}

PH - Plant height $(\mathrm{cm}), \mathrm{NCP}$ - Number of Clusters per plant, NBP - Number of branches per plant, NPP - Number of pod per plant, NSP - Number of Seeds per pod, HSW - hundred seed weight (g), SYP - Seed yield per plant (g) 
High GCV for number of fruits per plant, dry chilli yield per plot, was also reported by Munshi and Behera (2000), Varkey (2001), Gogoi and Gowtam (2002), Tembhurne et al., (2008), Sharma et al., (2010) and Kumar et al., (2012)

From the present study, it is evident that the genotypes studied may provide good source of material for further breeding programme. Therefore the information on the genetic parameters such as coefficient of variation, heritability, genetic advance can help the breeders to evolve suitable cultivars within a short time.

\section{References}

Gagoi, D. and Gautam, B.P. et al., 2002.Variability heritability and genetic advance in chilli.Agric. Sci. Digest., 22(2): 102-104.

Johnson, H.W., Robinson, H.P. and Comstoc, R.E. 1955. Estimation of genetic and environmental variability in soybean.Agronomy Journal, 47: 314318.

Kumar, D., Bahadur, V., Rangare, S.B.A. and Singh, D. 2012. Genetic variability, heritability and correlation studies in chilli (Capsicum annum L.).Hort. Flora Res. Spect., 1(3): 248-252.

Mamata K, Rajanna M.P and. Savita S.K2018.Assessment of Genetic Parameters for Yield and Its Related Traits in F2 Populations Involving
Traditional Varieties of Rice (Oryza sativa L.)ISSN: 2319-7706 Volume 7 Number 01.

Munshi, A.D. and Behera, T.K. et al., 2000. Genetic variability, heritability and genetic advance for some traits in chillies (Capsicum annum L.).Veg. Sci., 27(1): 39-41

Paikhomba N, Arvind Kumar, Chaurasia AK and Prashant Kumar Rai* Assessment of Genetic Parameters for Yield and Yield Components in Hybrid Rice and Parents Paikhomba et al., J Rice Res 2014, 2:1

Rohit Yadav, Priyanka Rajpoot, OP Verma, PK Singh, Priyansh Singh Sharma, V.K., Semwal, C.S.andUniyal, S.P. 2010. Genetic variability and character association analysis in bell pepper (Capsicum annum L.). J. Hort. Forestry, 2(3): 58-65.

Shil, S and P.K. Bandopadhya et al., 2007. Retaining seed vigor and viability of mungbean by dry dressing treatments. J. Food Legumes., 20: 173-175.

Tembhurne, B.V., Revannappa and Kuchanur, P.H. 2008. Varietal performance, genetic variability and correlation studies in chilli (Capsicum annum L.). Kar. J. Agric. Sci., 20(1): 102-104.

Varkey, J.P et al., 2001. Variability, correlation, path analysis and genetic divergence in chilli (Capsicum annum L.).M.Sc. (Agri). Thesis, (Unpublished) submitted to G.A.U., S.K. Nagar, Gujarat.

\section{How to cite this article:}

Manivelan, K., M. Karthikeyan, K. K. Suvain and Palaniyappan, S. 2019. Genetic Variability, Heritability and Genetic Advance for Yield in Mung Bean [Vigna radiata(L.)Wilczek]. Int.J.Curr.Microbiol.App.Sci. 8(09): 2252-2255. doi: https://doi.org/10.20546/ijcmas.2019.809.259 